\title{
Intra-specific genetic divergence in rapeseed (BRASSICA NAPUS L.) genotypes estimated through SDS-PAGE of total seed proteins
}

\author{
Shahid Ali Khan ${ }^{1 *}$, Javed Iqbal ${ }^{1}$, Haris Khurshid ${ }^{2}$, Muhammad Zia ${ }^{1}$, \\ Zabta Khan Shinwari ${ }^{1}$, Malik Ashiq Rabbani ${ }^{2}$ \\ ${ }^{I}$ Department of Biotechnology, Quaid-i-Azam University, Islamabad, Pakistan \\ ${ }^{2}$ Plant Genetic Resources Institute, NARC, Islamabad, Pakistan \\ *Corresponding author E-mail: shahidalikhan29@yahoo.com
}

Copyright $(92014$ Shahid Ali Khan et al. This is an open access article distributed under the Creative Commons Attribution License, which permits unrestricted use, distribution, and reproduction in any medium, provided the original work is properly cited.

\begin{abstract}
Through biochemical technique of SDS-PAGE, 136 genotypes of rapeseed (Brassica napus L.) were characterized based on total seed storage proteins. The germplasm used in the study consisted of 135 accessions and one check cultivar obtained from Gene-bank of Plant Genetic Resources Institute (PGRI), NARC, and Islamabad, Pakistan. During this study $12.25 \%$ polyacrylamide gels were used and a total of 21 protein sub-units were observed among the genotypes. Out of these 21 bands, $16(76.19 \%)$ were polymorphic and the rest of $5(23.81 \%)$ were monomorphic. The 21 protein sub-units were found within the range of molecular weights from 6 to $180 \mathrm{kDa}$. The similarity coefficient among these genotypes ranged from 0.83 to 0.98 . The genotypes studied were divided into five major clusters through constructing the dendrogram on the basis of dissimilarity matrix using UPGMA (unweighted pair group method with arithmetic averages). Overall a low level of genetic divergence was found. So, it is suggested that to find out high level of genetic diversity among these genotypes 2-D gel electrophoresis along with other modern techniques should be practiced in future because SDS-PAGE technique alone is insufficient to fully explore the genetic diversity present in these genotypes.
\end{abstract}

Keywords: SDS-PAGE; Genotypes; Brassica napus L.; Polymorphic; Monomorphic; Electrophoresis; UPGMA.

\section{Introduction}

For every breeding and crop improvement program the first step is to evaluate and characterize genetic diversity of those crops. The exploration and characterization is also important for management and supervision of available germplasm. In that respect different techniques and procedures were applied in the past. The best one among these is the molecular markers. These are the most excellent tools to evaluate the genetic association between different crop germplasm. One of these molecular tools is SDS-PAGE (sodium dodecyl sulfate polyacrylamide gel electrophoresis) which is used to find out the diversity present in total seed proteins of the same and different species and also to differentiate the crop germplasm in to different varieties [1].

As compared to exploring the genetic diversity of crop germplasm through agro-morphological and phonotypical techniques, SDS-PAGE technique is preferred because it is not much affected by environmental factors [2].It is mostly applied to the total seed proteins for the purpose to separate them according to the differences found in their molecular weights [3]. This technique is being used by many other scientists and plant breeders in the past and they have found it simple, comparatively inexpensive and more effective than agro-morphological techniques [4], [5], [6], [7], [8], [9].

Among the crop families Brassicaceae family plays an important role in providing good quality and yield of edible oil. The important one among other members of this family is Brassica which is among the top 10 major economical and significant plant families consisting of about 3,500 species and 350 genera [10]. There are different species in Brassica family i.e., turnip, cauliflower, broccoli, brusssels sprouts, cabbage, weeds and various mustards which are so much important due to their presence in different food, feed, edible oil, etc [11]. Brassica is the most primitive plant among 
the cultivated ones which was grown about $1500 \mathrm{BC}$ [12]. In the genus Brassica the commanding position is occupied by Brassica napus L. Its seeds consist of 40 to $45 \%$ oil, $46.5 \%$ protein, $3.5 \%$ fats and $0.35 \%$ phosphorus [13]. Brassica napus L. has great importance due to its role in edible oil production. The major mode of pollination in it is selfpollination but upto $20 \%$ cross- pollination may occur [14]. It is considered one of the leading vegetable oil sources ranking third subsequent to soybean and palm oil in the world [15]. It is economically so much important consisting of essential vegetable and fodder crops, like oilseed rape, rutabaga and leaf rape. It is also grown as a horticultural product provider by northwestern Spain farmers in winter for several years [16]. It is most essential in the sense of vegetable oil and in worlds oilseed market it has second position after soybean [17]. The present study was carried out to estimate the genetic diversity found among 136 genotypes of Brassica napus L. at total seed protein level through biochemical technique of SDS-PAGE.

\section{Materials and methods}

Experimental Material: The present research study was carried out at Plant Genetic Resources Institute (PGRI), National Agricultural Research Center (NARC), and Islamabad, Pakistan. The experimental material consisted of 136 genotypes, including 135 accessions of Brassica napus and a check cultivar. The genotypes characterized during present study were obtained from PGRI, NARC, and Islamabad. The detail of these genotypes is given in Table 1.

Protein Extraction: To extract protein first of all the selected seed samples were ground with the help of pestle and mortar until fine powder was gained. After this in $1.5 \mathrm{ml}$ centrifuge tube 0.01 gram of very well powdered seed flour were taken and $400 \mu \mathrm{l}$ protein extraction buffer $(0.5 \mathrm{M}$ Tris- $\mathrm{HCl}(\mathrm{pH} 8.0), 0.2 \%$ Sodium dodecyl sulphate (SDS), 5M urea, and 1\% 2-mercaptoethanol) was added and properly mixed with small glass rod. As an indicator, to observe the movement of protein in the separation gel, bromophenol blue was also added to the extraction buffer. For the clarification of the extraction, the homogenates seed flour samples were carefully mixed through vortexing and then spun at the speed of $15,000 \mathrm{rpm}$ for 5 minutes centrifuged at room temperature. Through centrifugation the crude protein in the form of clear supernatant on the upper portion of the tube was recovered from where it was transferred to another centrifuge tube of $1.5 \mathrm{ml}$ and stored for gel electrophoresis at $-20^{\circ} \mathrm{C}$, while the pallet was discarded.

Gel electrophoresis: Gel electrophoresis of total seed protein was performed in $12.25 \%$ polyacrylamide slab gels in discontinuous buffer system following protocol of Laemmli [18]. Protein sample of $8.5 \mu 1$ was loaded into the wells of stacking gel. Electrophoresis was performed at $100 \mathrm{~V}$ for 3 hours until bromophenol blue marker reached to the bottom of the gel. Pre-stained protein ladder, within the range of 6 to $180 \mathrm{kDa}$ (BenchMark ${ }^{\mathrm{TM}}$ Prestained Protein Ladder, cat.no.10748-010, Lot no.1046147) was also run with protein samples for the comparison of molecular weights of respective protein bands. After completion of electrophoresis the electric supply were disconnected and the gels were stained with $2 \%$ commassie blue solution from 45 to 60 minutes. After staining the gels were destained by solution containing 5\% (v/v) acetic acid, 20\% (v/v) methanol and distilled water in the ratio of 5:20:75 (v/v) for about two hour. Data Analysis: Depending on the presence and absence of polypeptide protein sub-units similarity index was designed for total possible pairs of different protein types. To stay away from taxonomic weighing, existence of protein sub-unit was taken as indicative instead of the concentration of the protein sub-unit. In case of presence of protein sub-unit 1 was scored while 0 was score in case of absence of protein sub-unit and these presence and absence of protein sub-units was entered in a binary data matrix. Depending on the electrophoretic band spectra, similarity index (S) was designed for all achievable pairs of protein type electrophoregrams by the subsequent formula [19]:

$\mathrm{S}=\mathrm{W} /(\mathrm{A}+\mathrm{B}-\mathrm{W})$

Where $\mathrm{S}=$ similarity index, $\mathrm{W}=$ Number of bands of common mobility, $\mathrm{A}=$ Number of bands in protein type ' $\mathrm{A}$ ', $\mathrm{B}=$ Number of bands in protein type 'B', After generating the similarity matrix it was converted into a dissimilarity matrix (Dissimilarity = 1 - similarity) and was used to construct dendrogram by UPGMA (Unweighted pair-group method with arithmetic averages) [19]. All the analyses were carried out using statistical package NTSYS-pc, version 2.1 (Applied Biostatistics Inc., USA).

\section{Results}

During the present study 136 genotypes of Brassica napus L. were characterized through SDS-PAGE. Total of 21 polypeptide bands were observed. The molecular weights of these bands were within the range of 6 to $180 \mathrm{kDa}$. Apart from these many other polypeptide bands of lower molecular weights were also found but they were not brought into the record because they were not reproducible. Out of total 21 bands, $16(76.19 \%)$ were polymorphic and the rest of 5 $(23.81 \%)$ were monomorphic (Figure 1$)$. The polymorphic protein sub-units were found in the entire four regions made of the gels but they were different in number. In region A of the gels 4 protein sub-units were found with their molecular weights ranged from about 136 to $180 \mathrm{kDa}$. Among these four protein sub-units, 3 were polymorphic and 1 was monomorphic. In the second i.e. B region of the gels, 6 protein sub-units were observed and these all were polymorphic. The molecular weights of these protein sub-units were found within the range of about 82 to $115 \mathrm{kDa}$. 
Table 1: Brassica napus L. Genotypes Used In Present Study for SDS-PAGE Analysis.

\begin{tabular}{|c|c|c|c|c|c|c|c|c|}
\hline No & Accession & Collection area & No & Accession & Collection area & No & Accession & Collection area \\
\hline 1 & 1323 & Unknown & 47 & 24246 & Unknown & 93 & 27382 & China \\
\hline 2 & 1672 & Unknown & 48 & 24247 & Unknown & 94 & 27383 & China \\
\hline 3 & 1684 & Unknown & 49 & 24248 & Unknown & 95 & 27385 & China \\
\hline 4 & 1687 & Unknown & 50 & 24250 & Unknown & 96 & 27386 & China \\
\hline 5 & 1693 & Pakistan & 51 & 24251 & Unknown & 97 & 27387 & China \\
\hline 6 & 1694 & Pakistan & 52 & 24253 & Unknown & 98 & 27388 & China \\
\hline 7 & 1695 & Pakistan & 53 & 24254 & Unknown & 99 & 27390 & China \\
\hline 8 & 1697 & Pakistan & 54 & 24255 & Unknown & 100 & 27392 & China \\
\hline 9 & 1698 & Pakistan & 55 & 24257 & Unknown & 101 & 27393 & China \\
\hline 10 & 1699 & Pakistan & 56 & 24259 & Unknown & 102 & 27394 & China \\
\hline 11 & 1700 & Pakistan & 57 & 26067 & Netherlands & 103 & 27395 & China \\
\hline 12 & 1701 & Pakistan & 58 & 26217 & Germany & 104 & 27397 & China \\
\hline 13 & 1702 & Pakistan & 59 & 26218 & Germany & 105 & 27398 & China \\
\hline 14 & 1705 & Pakistan & 60 & 26068 & Netherlands & 106 & 27399 & China \\
\hline 15 & 1706 & Pakistan & 61 & 24844 & Pakistan & 107 & 27400 & China \\
\hline 16 & 1708 & Pakistan & 62 & 24848 & Pakistan & 108 & 27401 & China \\
\hline 17 & 1720 & Unknown & 63 & 24849 & Pakistan & 109 & 27402 & China \\
\hline 18 & 16104 & Pakistan & 64 & 24851 & Pakistan & 110 & 27403 & China \\
\hline 19 & 16105 & Pakistan & 65 & 24853 & Pakistan & 111 & 27404 & China \\
\hline 20 & 22851 & Pakistan & 66 & 24854 & Pakistan & 112 & 27406 & China \\
\hline 21 & 22853 & Pakistan & 67 & 24855 & Pakistan & 113 & 27408 & China \\
\hline 22 & 22855 & Pakistan & 68 & 24856 & Pakistan & 114 & 27410 & China \\
\hline 23 & 22856 & Pakistan & 69 & 24858 & Pakistan & 115 & 27411 & China \\
\hline 24 & 22858 & Pakistan & 70 & 24859 & Pakistan & 116 & 27412 & China \\
\hline 25 & 23633 & Unknown & 71 & 24860 & Pakistan & 117 & 27413 & China \\
\hline 26 & 24169 & Unknown & 72 & 24862 & Pakistan & 118 & 27416 & China \\
\hline 27 & 24170 & Unknown & 73 & 24864 & Pakistan & 119 & 27418 & China \\
\hline 28 & 24211 & Unknown & 74 & 24867 & Pakistan & 120 & 27420 & China \\
\hline 29 & 24212 & Unknown & 75 & 24868 & USA & 121 & 27421 & China \\
\hline 30 & 24213 & Unknown & 76 & 24874 & Pakistan & 122 & 27422 & China \\
\hline 31 & 24214 & Unknown & 77 & 24878 & Pakistan & 123 & 27424 & China \\
\hline 32 & 24215 & Unknown & 78 & 24882 & Pakistan & 124 & 27425 & China \\
\hline 33 & 24217 & Unknown & 79 & 24890 & Pakistan & 125 & 27426 & China \\
\hline 34 & 24219 & Unknown & 80 & 24892 & Pakistan & 126 & 27428 & China \\
\hline 35 & 24221 & Unknown & 81 & 24893 & Pakistan & 127 & 27429 & China \\
\hline 36 & 24222 & Unknown & 82 & 24896 & Pakistan & 128 & 27430 & China \\
\hline 37 & 24229 & Unknown & 83 & 24897 & Pakistan & 129 & 27432 & China \\
\hline 38 & 24230 & Unknown & 84 & 24898 & Pakistan & 130 & 27898 & China \\
\hline 39 & 24231 & Unknown & 85 & 24899 & Pakistan & 131 & 27899 & China \\
\hline 40 & 24234 & Unknown & 86 & 24901 & Pakistan & 132 & 27900 & China \\
\hline 41 & 24236 & Unknown & 87 & 24904 & Pakistan & 133 & 27901 & China \\
\hline 42 & 24237 & Unknown & 88 & 24905 & Pakistan & 134 & 27902 & China \\
\hline 43 & 24239 & Unknown & 89 & 24906 & Pakistan & 135 & 27903 & China \\
\hline 44 & 24241 & Unknown & 90 & 24907 & Pakistan & 136 & KP-Raya & \\
\hline 45 & 24242 & Unknown & 91 & 27380 & China & & & \\
\hline 46 & 24245 & Unknown & 92 & 27381 & China & & & \\
\hline
\end{tabular}

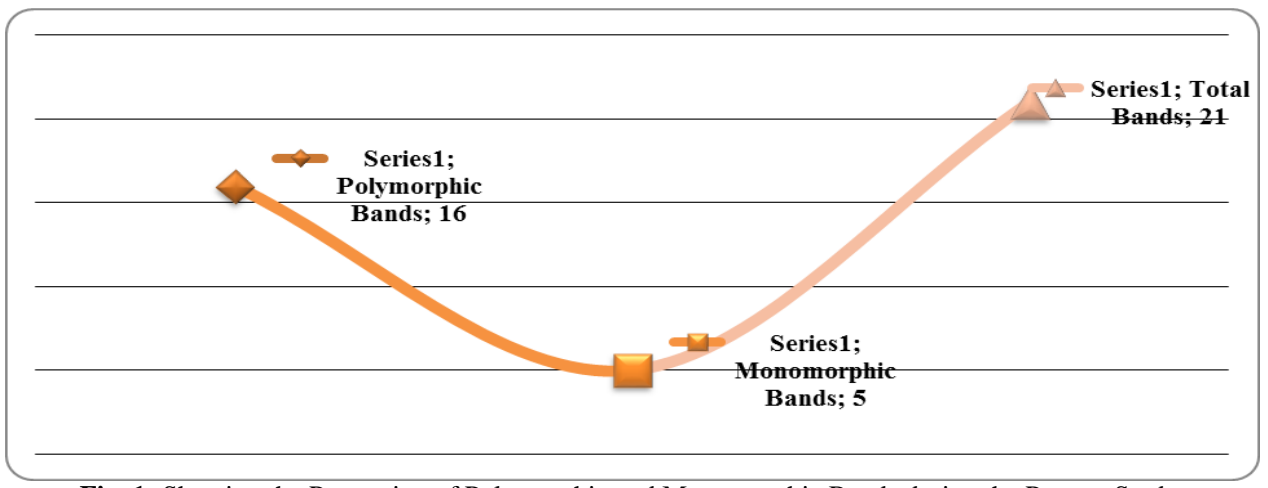

Fig. 1: Showing the Proportion of Polymorphic and Monomorphic Bands during the Present Study. 
Seven protein bands were found in the third i.e. C region of the gels within the range of about 26 to $69 \mathrm{kDa}$ of molecular weights. Among these 7 protein sub-units 6 were polymorphic and 1 was monomorphic. Similarly in the last region of the gels which is mentioned as region $\mathrm{D}$, a total of 4 bands of proteins were observed. These 4 protein subunits were found within the range of about 6 to $19 \mathrm{kDa}$ of molecular weights. In these 4 protein sub-units only 1 was polymorphic and the rest of 3 were monomorphic. The gel showing the electrophoretic pattern of protein sub-units in Brassica napus L. genotypes during the present study is given in Figure 2.

The range of similarity coefficient among these genotypes was from 83 to $98 \%$. Based on dissimilarity matrix, dendrogram was constructed to depict the relationship among various accessions (Figure 3). The study dendrogram was delimitated into groups, by putting those genotypes in the same group in which the total seed protein were found to have the same polypeptide banding pattern (Table 2) and all the genotypes were divided into five main clusters (Figure 4).

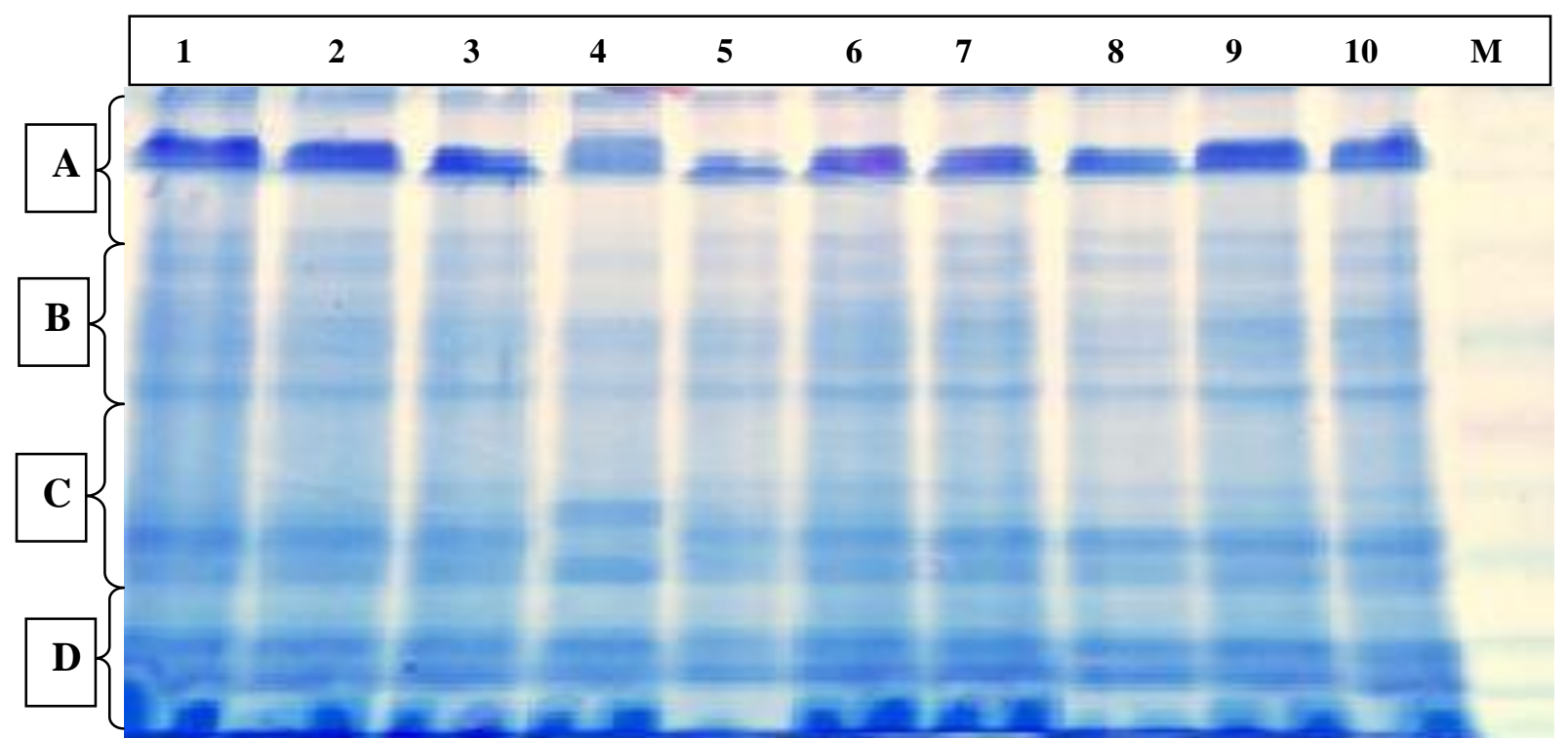

Fig. 2: Electrophoretic Banding Pattern of Brassica Napus L. Genotypes Generated through SDS-PAGE of Total Seed Storage Proteins. M Represents Molecular Size Marker, While Numbers From 1-10 Represent Accessions 23633, 24247, 27390, Khanpur-Raya, 27402, 27408, 27385, 27386, 27432 and 27416, Respectively.

Cluster-I was the largest among all found to have 9 sub-groups i.e. Group-A, B, C, D, K, E, F, G and M, and four solitary accessions i.e. 24905, 24859, 27400 and 1694. Total of 109 genotypes were included in Cluster-I. Cluster-II of the study dendrogram was found to have four solitary accessions i.e. 24213, 24259, 24890 and 24899. Cluster-III had one group i.e. Group-H, and three accessions 24844, 1706 and 24907 containing total of 5 genotypes. Similarly in cluster-IV groups-I, J, N, L and six solitary accessions, 1672, 1684, 24222, 24225, 27416 and 27898 were found. Total genotypes found in this cluster were 17. In the last i.e. cluster-V only one accession 16105 was found (Table 3). The division of all the groups and genotypes into same and different clusters were because of their similarity and differences among them, respectively. It was not just because of its origination from the same geographical region, because most of the genotypes from the same geographical region were found in different clusters.

\section{Discussion}

Among various techniques used for estimation of crops genetic diversity SDS-PAGE is considered important technique to find out pattern of total seed protein which is relatively less affected by different environmental factors [20], [21]. It is relatively simple technique and found to be inexpensive. Utilization of SDS-PAGE technique has been suggested as instrumental in estimation of genetic variation of different crop germplasm and its wild relatives [22].

About the genetic diversity through SDS-PAGE of Brassica between different species and within species very little evidence is available which agree with the recent study of Brassica napus L. genotypes. These differenced in results could be attributed to differences in germplasm used, analyses modification and lab conditions. There are still some difficulties in finding out the differences found in mustard genotypes which have close association with each other through SDS-PAGE. But it has played very important role in estimation of genetic diversity based on protein profile pattern of locally collected germplasm from different regions of the country [23].

During the present study Brassica napus L. genotypes were found to have the similarity within the range of 83 to $98 \%$, which were found in close agreement with that of Turi et al [5], who recorded similarity within the range of 45 to $98 \%$ during their characterization of Brassica genotypes. The present findings about genetic similarity range were also comparable with that of Shinwari et al [8], who observed 60 to $100 \%$ genetic similarity among the genotypes of Eruca 
sativa. Similarly during characterization of Brassica carinata, Zada et al [9] also found comparable agreement with present findings. They found the genetic similarity within the range of 50 to $100 \%$.

The dendrogram constructed through dissimilarity matrix using UPGMA (unweighted pair groups method with arithmetic averages) divided all the genotypes in to five main clusters. Zada et al [9] also found five divisions of their studied genotypes of Brassica carinata constructing dendrogram through dissimilarity matrix using UPGMA. Similar results about clustering of genotypes were also noted by Nasr et al [24] in genotypes of Brassica napus L. and Mukhlesur et al [25] in Brassica rapa. The differences found between the present and previous findings in number of protein sub-units may be because of difference in studied genotypes, difference in percentage of the gel used and selection of the protein sub-units during data scoring.

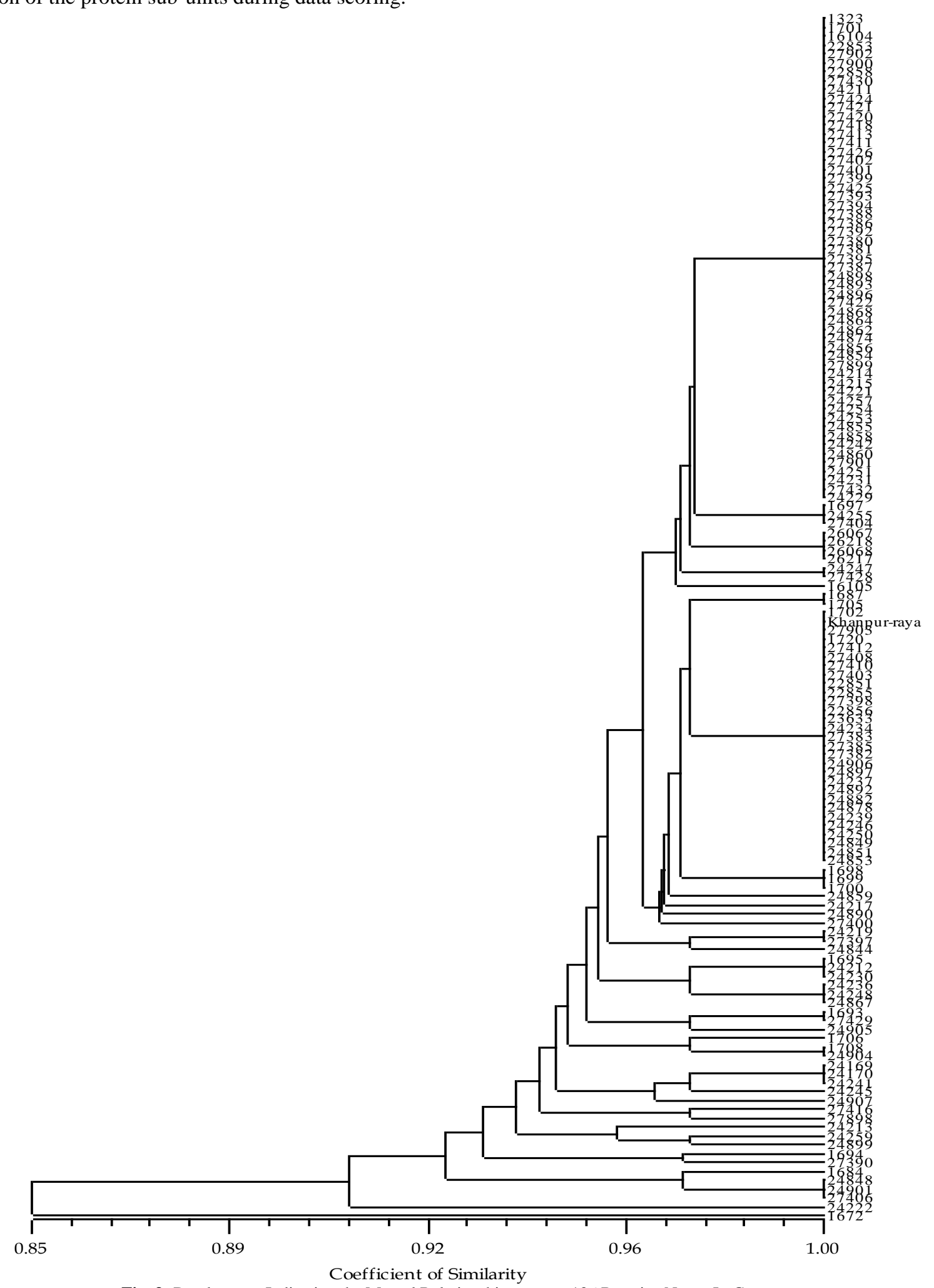

Fig. 3: Dendrogram Indicating the Mutual Relationships among 136 Brassica Napus L. Genotypes. 
Table 2: Grouping of Studied Brassica napus L. Genotypes Based on Same Polypeptide Profile.
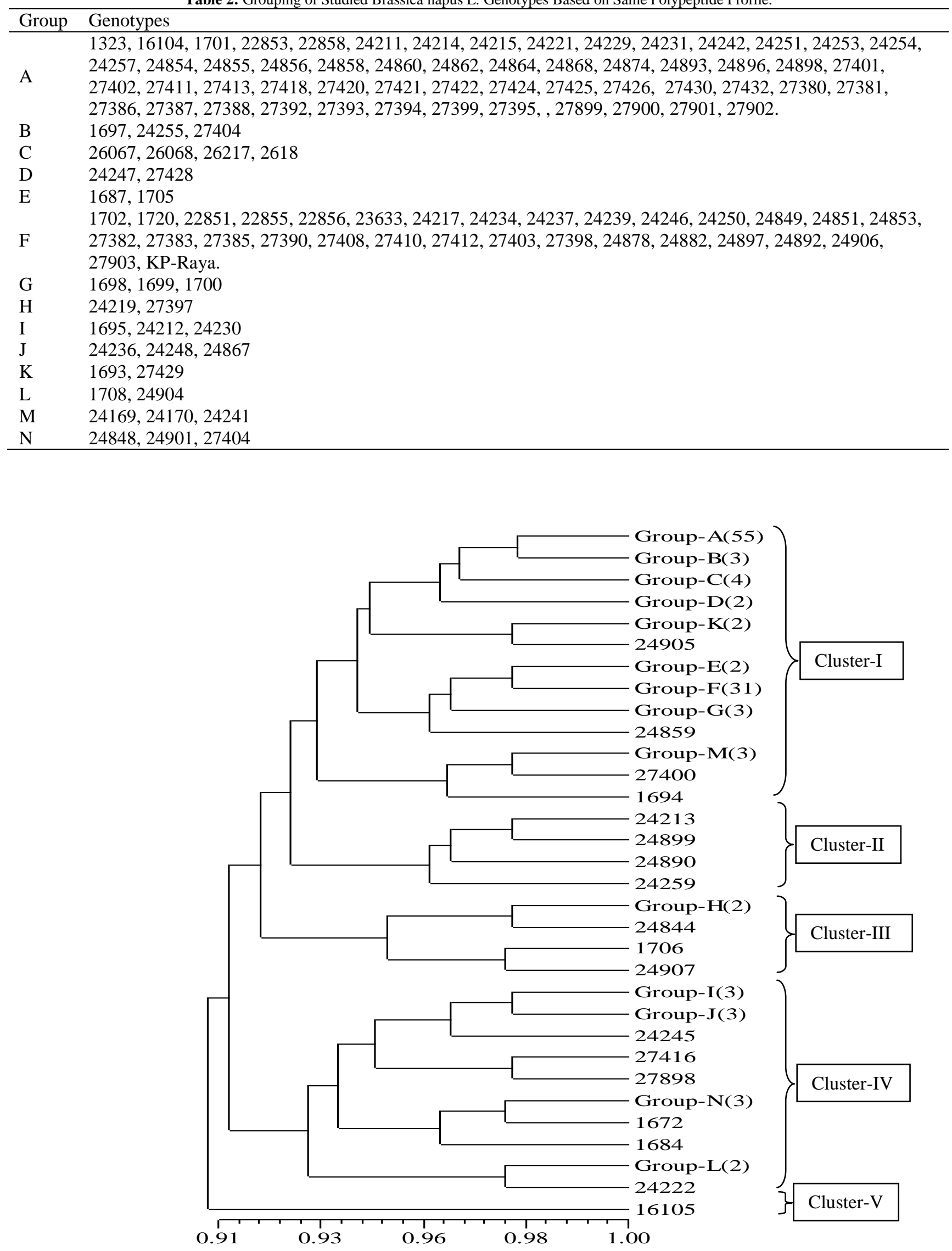

Fig. 4: Dendrogram Showing the Relationship among Different Groups and Accessions of Brassica napus L. Based On SDS-PAGE Of Total Seed Proteins. 
Table 3: Clustering of 136 Brassica napus L. Genotypes Based on Cluster Analysis Using SDS-PAGE.

\begin{tabular}{|c|c|c|}
\hline Cluster & $\begin{array}{l}\text { No. of } \\
\text { genotypes }\end{array}$ & Genotypes \\
\hline I & 109 & $\begin{array}{l}1323,1687,1693,1694,1697,1698,1699,1700,1705,1701,1702,1720,16104,22851, \\
22853,22855,22856,22858,23633,24169,24170,26067,26218,26068,26217,24211, \\
24214,24215,24217,24221,24229,24231,24234,24237,24239,24241,24242,24246, \\
24247,24250,24251,24253,24254,24255,24257,24849,24851,24853,24854,24855, \\
24856,24858,24859,24860,24862,24864,24868,24874,24878,24882,24892,24893, \\
24896,24897,24898,27380,27381,27382,27383,27385,27386,27387,27388,27390 \\
27392,27393,27394,27395,27398,27399,27400,27401,27402,27403,27404,27408, \\
27410,27411,27412,27413,27418,27420,27421,27422,27424,27425,27426,27428, \\
27429,27430,27432,27899,27900,27901,27902,27903,24905,24906, \text { KP Raya. }\end{array}$ \\
\hline II & 4 & $24213,24899,24890,24259$ \\
\hline III & 5 & $24844,1706,24907,24219,27347$ \\
\hline IV & 17 & $\begin{array}{l}1672,1684,1695,1708,24212,24222,24230,24236,24245,24248,27416,27406,24867, \\
27898,24901,24904,24899 .\end{array}$ \\
\hline $\mathrm{V}$ & 1 & 16105 \\
\hline
\end{tabular}

\section{Conclusion}

From the present study it is concluded that for getting promising and high level of intra-specific genetic diversity, along with SDS-PAGE other modern molecular techniques should be used in future to quantify even minor genetic discrepancies in the genetic makeup of closely related species. Because only using SDS-PAGE is not sufficient to fully explore the differences found within the species; however it can be a good and cheap tool to find out inter-specific genetic diversity.

\section{Acknowledgements}

The authors are thankful to the Plant Genetic Resources Institute (PGRI), National Agricultural Research Centre (NARC), and Islamabad for providing the seed material used and extending laboratory facilities throughout the present study. Financial support is gratefully acknowledged from Pakistan Science Foundation, Islamabad, Pakistan and Dow Agro-Sciences Inc., Canada through the projects.

\section{References}

[1] Isemura, T., N. Shiyo, M. Shigeyuki, Y. Michihiro, N. Hiroo, I. Masayoshi and K. Osamu. 2001. Genetic variation and geographical distribution of Azuki bean (Vignaangularis) landraces based on the electrophoregram of seed storage proteins. Breed. Sci., 51: 225-230.

[2] Tanksley, S.D. and R.A. Jones. 1986. Application of alcohol bedyrogenaseallozymes in testing the genetic purity of F1 hybrids of tomato. Hort. Sci., 16: 179-181.

[3] Ullah, I., I.A. Khan, H. Ahmad, S.U. Gafoor, S. Gul, I. Muhammad and M. Ilyas. 2010. Seed storage protein profile of rice varieties commonly grown in Pakistan. Asian J. Agric. Sci., 2: 120-123.

[4] Iqbal, J., Z.K, Shinwari, M.A. Rabbani and S.A. Khan. 2014. Genetic Variability Assessment of Maize (Zea mays L.) Germplasm Based on Total Seed Storage Proteins Banding Pattern Using SDS-PAGE. EAR. 2: 2144-2160.

[5] Turi, N.A., Farhatullah, M.A. Rabbani, N.U. Khan, M. Akmal, Z.H. Pervaiz and M.U. Aslam. 2010. Study of total seed storage protein in indigenous Brassica species based on sodium dodecyl sulfate polyacrylamide gel electrophoresis (SDS-PAGE). Afr. J. Biotech., 9: 7595-7602.

[6] Akbar, F., N. Yousaf, M.A. Rabbani, Z.K. Shinwari and M.S. Masood. 2012. Study of total seed proteins pattern of sesame (Sesamumindicum L.) landraces via sodium dodecyl sulfate polyacrylamide gel electrophoresis (SDS-PAGE). Pak. J. Bot., 44: 2009-2014.

[7] Khurshid, H. and M.A. Rabbani. 2012. Comparison of electrophoretic protein profiles from seed of different oilseed Brassica cultivars. $J$. Pub. Health \& Bio. Sci., 1: 36-42.

[8] Shinwari, S., F. Akbar, M.A. Rabbani, A.S. Mumtaz and Z.K. Shinwari. 2013. Evaluation of genetic diversity in different genotypes of Eruca sativa from Pakistan by SDS-PGE analysis. Pak. J. Bot., 45: 1235-1240.

[9] Zada, M., Z.K. Shinwari, N. Zakir and M.A. Rabbani. 2013. Study of total seed storage proteins in Ethiopian mustard (Brassica carinataa. Braun) germplasm. Pak. J. Bot., 45: 443-448.

[10] Warwick, S.I., A. Francis and J.L. Fleche. 2000. Guide to wild germplasm of Brassica and allied crops (tribe brassicaceae). Available from http://www.brassica.info/info/publications/guidewild/Guide_ed.3_Introd_16July2009.pdf

[11] Willis, J.C. 1973. A Dictionary of the Flowering Plants and Ferns (Eighth Edition).Cambridge University Press, Cambridge, 1245p.

[12] Prakash, S. 1980. Cruciferous oilseeds in India. In: Brassica Crops and Wild Allies- Biology and Breeding. Tsunoda S, Hinata K and Gomez-Campo C (Eds.) Japan Scient. Soc.Press, Tokyo.pp.151-163.

[13] Downy, R.K. and G. Robbelen. 1989. Brassica Species. In: G. Robbelen, et al. (Eds). Oil Crops of the World. McGraw-Hill Publishing Company.

[14] Grant, I. and W.D. Beversdorf. 1985. Heterosis and combining ability estimated in spring planted oilseed rape (B. napus). Canadian J. Cytol., 27: $472-478$.

[15] Miri, H.R. 2007. Morpho-physiological basis of variation in rapeseed (Brassica napus L.) yield. Int. J. Agric. Biol., 9: 701-706.

[16] Cartea, M.E., P. Soengas, A. Picoaga and A. Ordás. 2005. Relationships among Brassica napus L. germplasm from Spain and Great Britain as determined by RAPD markers. Genet.Resour. Crop Evol. 52: 655-662.

[17] Hasan, M., F. Seyis, A.G. Badani, J.P. Kuhnemann, W. Friedt, W. Luhs and R.J. Snowdon. 2006. Analysis of genetic diversity in the Brassica napus L. gene pool using SSR markers. Genet.Resour. Crop.Evol., 53: 793-802. 
[18] Laemmli, U.K. 1970. Cleavage of structural proteins during the assembly of the head of bacteriophage T4.Nature, 227: 680-685.

[19] Sneath, P.H. and R.R. Sokal. 1973. Numerical Taxonomy: The Principles and Practice of Numerical Classification. W.F. Freeman \& Co., San Francisco, USA. 573p.

[20] Javaid, A., A. Ghafoor and R. Anwar. 2004. Seed storage protein electrophoresis in groundnut for evaluating genetic diversity. Pak. J. Bot., 36: $25-29$.

[21] Iqbal, S.H., A. Ghafoor and N. Ayub. 2005. Relationship between SDS-PAGE markers and Ascochytablight in chickpea. Pak. J. Bot., 37: 8796.

[22] Thanh V.O.C. and Y. Hirata. 2002. Seed storage protein diversity of three rice species in the Mekong Delta. Biosphere Conservation, 4: 5967.

[23] Rabbani, M.A., A.A. Qureshi, M. Afzal, R. Anwar and S. Komatsu. 2001. Characterization of mustard [Brassica juncea (L.) Cezern. \& Cross] germplasm by SDS-PAGE of total seed protein. Pak. J. Bot., 33: 173-179.

[24] Nasr, N., M. Khayami, R. Heidari and R. Jamei. 2006. Genetic diversity among selected varieties of Brassica napus (Cruciferae) based on the biochemical composition of seeds. JUST, 32: 37-40.

[25] Mukhlesur, R.M., Y. Hirata and S.E. Alam. 2004. Genetic variation within Brassica rapa cultivars using SDS-PAGE for seed protein and isozyme analysis. J. Bio. Sci., 4: 239-242. 